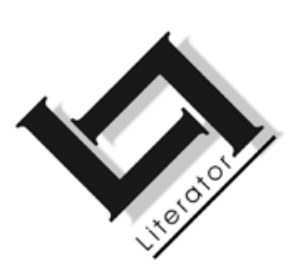

\title{
The grotesque as it appears in Western art history and in lan Marley's creative creatures
}

\author{
Rita Swanepoel \\ Department History of Art \\ North-West University \\ Potchefstroom Campus \\ POTCHEFSTROOM \\ E-mail: rita.swanepoel@nwu.ac.za
}

\begin{abstract}
The grotesque as it appears in Western art history and in lan Marley's creative creatures

This article presents a theoretical exploration and reading of the notion of the grotesque in Western history of art to serve as background to the reading of the original creatures in the "Tracking creative creatures" project. 1 These creatures were drawn by Marley, based on imaginary creatures narrated by his five year-old son, Joshua. The focus in this article is on the occurrence of the grotesque in paintings and drawings. Three techniques associated with the grotesque are identified: the presence of imagined fusion figures or composite creatures, the violation and exaggeration of standing categories or concepts, and the juxtaposition of the ridiculous and the horrible. The use of these techniques is illustrated in selected artworks and Marley's creatures are then read from the angle of these strategies.
\end{abstract}

1 To understand the frame within which this research has been done, reference should be made to the introductory article by Greyling and Marley. It is important to keep in mind that the articles stemming from this project are individual contributions. It was not a team project in the sense that authors responded to each other's contributions. 


\section{Opsomming}

\section{'n Ondersoek na die groteske in Westerse kunsgeskiedenis en in lan Marley se kreatiewe kreature}

Hierdie artikel bied 'n teoretiese ondersoek na en 'n lees van die voorkoms van die groteske in Westerse kunsgeskiedenis as 'n agtergrondstudie tot die lees van die oorspronklike kreature in die projek, "Op die spoor van kreatiewe kreature". 2 Die kreature is deur lan Marley geteken, gebaseer op verbeeldingskreature wat deur sy sesjarige seun, Joshua aan hom vertel is. Die toespitsing in hierdie artikel is op die groteske in sketse en skilderkuns. Drie tegnieke wat met die groteske geassosieer word, word geïdentifiseer, te wete die skep van verbeeldingsen saamgestelde figure, 'n afwyking van die normale en 'n jukstaposisionering van die belaglike en die afskrikwekkende. Die aanwending van hierdie tegnieke word geïllustreer in geselekteerde kunswerke en Marley se kreature word dan vanuit die hoek van hierdie tegnieke gelees.

\section{Introduction}

In the context of artworks the word grotesque is generally used as a vague term to describe inter alia strange, ugly, fantastic, ridiculous yet frightening, demonic, absurd, distorted or unfamiliar shapes and forms. Motifs that are often present in the grotesque vary from monsters and composite creatures to mythological and prehistoric animals, as indicated by Carroll (2003:295):

If one thing is agreed upon by historians of the grotesque, it is that the concept appears unstable, referring to a wide gamut of material ranging from mythological figures ..., to perhaps pagan residues like gargoyles, to the imagery of Bosch, Brueghel, Dürer, Goya, Doré, and innumerable caricaturists, to writers such as Rabelais, Swift, Hoffman, Poe and Kafka, to the surrealists, and ... to countless producers of contemporary mass art.

Carroll then proceeds to ask whether there is any way to find unity in such an unruly concept and suggests that maybe the concept of the grotesque is so heterogeneous that it is itself grotesque.

2 Om die raamwerk waarbinne hierdie navorsing gedoen is te verstaan, word na die inleidende artikel van Greyling and Marley verwys. Dit is belangrik om in gedagte te hou dat artikels voortspruitend uit hierdie projek individuele bydraes is. Dit was nie navorsing in groepsverband waar skrywers op mekaar se artikels gereageer het nie. 
This article presents a theoretical exploration of the notion of the grotesque in the Western history of art to serve as background to the study and reading of the original creatures in the Tracking creative creatures project. These creatures - drawn by South African artist lan Marley - were based on imaginary creatures narrated to him by his five year old son, Joshua, who said to his father, "Daddy, let me tell you a creature".

The focus is on the portrayal of the grotesque in paintings and drawings. The reason for this is twofold. On the one hand these media correspond with the drawing medium used by Marley. On the other hand Barasch (1971:18) points out that only paintings originally earned the permanent designation grottesche from grotta, referring to the caves in which archaeologists in the late fifteenth century discovered ancient Roman statues, architectural volutes and paintings of composite creatures.

In order to explore the grotesque within an aesthetic framework, general conceptions regarding the grotesque are discussed, followed by an investigation of the notion of the grotesque as it appears in Western art history. Three techniques associated with the grotesque are identified. The use of these techniques is illustrated in selected works in Western art. Marley's creatures are then briefly read from the perspective of his use of these techniques.

\section{General conceptions regarding the grotesque}

The Penguin English Dictionary describes the word grotesque (as a noun) as a style of decorative art in which incongruous or fantastic human and animal forms are interwoven with natural motifs (e.g. foliage). As such, the grotesque is characterised by a departure from the natural, the expected, or the typical. Kayser (1981:17) states that grotesque forms are created by artists to induce in the viewer an uneasy and alienated emotional experience of a "world totally different from the familiar one"3 (cf. also Connelly, 2003:5; Fingesten, 1984:419; Barasch, 1985:4). Harpham (1976:462) explains that the grotesque serves as a structure of estrangement.

In Western art history there is a remarkable variation in the uses of the term grotesque. Carroll (2003:294) suggests that the reason for

3 This "world totally different from the familiar one" is derived from Sir Thomas Browne's words when stated in his Religion Medici (1642): "[t]here is no grotesca in nature" (Browne, 2000 [1642]; Lawson, 1965:122). 
this is that art historians employing this term work from different historical traditions. In classical times the grotesque was relegated to a submissive, ornamental role. Connelly (2003:3-4) states that modernism has had a far more complex and conflicted relationship with the grotesque in comparison to its classical forebears. In the late 20th and in the 21st century the grotesque is often found in and closely connected to the expansion of the entertainment industry in the form of mechanised human beings and animated creatures (Carroll, 2003:291 ff.).

Connelly (2003:5) further mentions that the term grotesque itself is problematic because it springs from an accidental mistake. The term was first use to describe the fantasy figures decorating a Roman villa. Because these rooms were excavated below ground level, Renaissance observers misconceived them to be grottos.

Because the grotesque describes the aberration from ideal form or from accepted convention, Connelly states that it identifies a class of imagery that has never fitted comfortably within the boundaries traditionally set by either aesthetics or art history for its objects of inquiry. It therefore seems as though the grotesque in its portrayal of the ugly, misshapen, exaggerated and even formless, "destabilises certainties, pushes boundaries, shifts expectations and calls current beliefs into question" (Connelly, 2003:2, 5). This indicates that the grotesque is not a fixed concept but a fluid one. As such, it embodies "both a promise of freedom and a foreshadowing of chaos" (Rosen, 1990:127). Rosen (1990:132) thus declares that the grotesque can be regarded as creation rather than imitation.

Fingesten (1984:420) correctly observes that there is an undeniable overlap between the categories of the grotesque and the fantastic. According to him there is in grotesque art always a unity between concept, subject and form, as no definition of the grotesque can solely depend upon formal properties (Fingesten, 1984:420-425). This is why the grotesque often has an emotional as well as intellectual impact on both the creator and the viewer.

In some cases the grotesque may even be "purposeless", meaning that it may not be intended. Unintentional grotesquery may also be possible due to subjectivity and the inevitable variation in reception. However, by a process of consensus, comparison and argument one could well decide whether the grotesque is present in a work of art (Thomson, 1972:65-70). As a result, although it was not the artist's intention, a work can still be viewed as grotesque because the form, subject matter and concept are experienced as grotesque. 
Fingesten (1984:419) suggests that the grotesque should be viewed as a symbolic category of art. He points out that the grotesque "expresses psychic currents from below the surface of life, such as nameless fears, complexes, nightmares and Angst". This could be one explanation for the creation of the unintentional grotesque. The grotesque may then serve as an escape from reality which leads to a way of dealing with fear. In other words it implies a psychological way of taking care of one's emotional well-being. This may also be an explanation why one often finds in several grotesque works a simultaneous presence of the ridiculous and the horrible (cf. Barasch, 1971; Thomson, 1972; Jennings, 1963; Connelly, 2003; Kayser, 1981).

\section{Vitruvius' and Horace's notion of the grotesque}

The word grotesque initially derives from grotto meaning a cave. In "caves" or rather underground rooms near the Baths of Titus 4 archaeologists in the late fifteenth century discovered ancient Roman free-standing statues and wall and ceiling decorations. These artworks consist of composite creatures: human torsos with sprout leafy tendrils for legs or faun's ears that spring into architectural volutes (Barasch, 1971:17 ff.; Connelly, 2003:7).

Classical thinking on art can be deduced from the writings of Vitruvius (c.50-10 BC), an architect during the reign of Augustus, who was a pioneer in formulating the philosophical and theoretical views of his time. Vitruvius based his views pertaining to art on the classical notions of symmetry, logic, imitation, as well as the laws of nature and proportion. He therefore disapproved of fantasy figures and condemned artists' painting of such figures. According to him artists who produced such works had exercised "improper taste" and had acquired fierce habits in departing from "a reasoned scheme of decoration" (Barasch, 1971:28). In his De Architectura (c.28 BC) Vitruvius firmly declares that

[a]ll these motifs taken from reality are now rejected by an unreasonable fashion. For our contemporary artists decorate the walls with monstrous forms rather than reproducing clear images of the familiar world. Instead of columns they paint fluted stems with oddly shaped leaves and volutes, and instead

$4 \quad$ See Barasch (1971:17 ff.) for a detailed description of grottos, as well as the explanation in footnote 2 of the golden house of Nero that was discovered beneath the ruins of the Baths of Titus. 
of pediments arabesques, the same with candelabra and painted aedicules, on the pediments of which grow dainty flowers unrolling out of roots and topped without rhyme or reason, by figurines. The little stamps finally, support half figures crowned by human or animal heads. Such things, however, never existed, do not now exist and shall never come into being. (Quoted in Kayser, 1981:20.)

Vitruvius' contemporary, the leading Roman lyric poet Horace (65 BC-8 BC) held similar views on art. In the introductory lines to his Ars poetica (Horace, 2000 [18 BC]), Horace condemned the use of composite creatures in art as foolish and ridiculous

Suppose a painter to a human head

Should join a horse's neck, and wildly spread

The various plumage of the feathered kind

O'er limbs of different beasts, absurdly joined;

Or if he gave to view a beauteous maid

Above the waist with every charm arrayed,

Should a foul fish her lower parts infold,

Would you not laugh such pictures to behold?

According to Rosen (1990:128) these rejections stem from reproaches against a barbarous and unacceptable fashion that was associated with the decline of Roman art. Composite creatures containing human and animal figures intertwined with foliage were seen as a violation of common sense and plain observation. Such figures were further regarded as the "excessive invention of overheated imagination" (Harpham, 1976:461; Summers, 2003:22).

Summers (2003:22) states that both Vitruvius and Horace appeal in the Stoic manner to nature as a criterion for restraint. In this way both authors contributed significantly to what might be called the conventional definition of classicism in the centuries to follow. Vitruvius' De Architectura indeed served as a basis for some of the commentaries and books of instruction in painting and architecture during the period from the fifteenth to the eighteenth century. This is confirmed by Barasch (1971:29) who points out that humanists discovered in this condemnation an attack on the ornate style in general and against the grotesques in particular (cf. also Thomson, 1972:12).

\section{Notions of the grotesque during the Renaissance}

After the discovery of composite creatures in the grottos, such figures became a popular mode of expression during the Renais- 
sance. Summers (2003:23-24) points out that both in antiquity and the Renaissance, grotteschi were also called "monsters". These monsters - known as chimeras 5 - were unnatural combinations of natural things, or parts of things. The power to make such combinations was that of pure fantasy or imagination.

During the fifteenth century these monsters portrayed in art were again condemned as can be seen from the writings of Leon Battista Alberti (1404-1472) whose views agreed with those expressed by Vitruvius and Horace. He specifically objected to the unregulated, extravagant and fantastic style of grotesque ornamentation as well as to the grotesquely proportioned figures and crowded scenes painted by artists in Northern Europe, especially the Dutch kermis painters (Barasch, 1971:25, 28; Connelly, 2003:6-7).

In the sixteenth century Benvenuto Cellini (1500-1577) and Georgio Vasari (1511-1574) came out in opposition to the views of Vitruvius, Horace and Alberti, when they voiced their approval and support for artists employing the grotesque. This greatly modified the views on art in the debates that re-emerged during the cinquecento and mannerist periods (cf. Barasch, 1971:31; Connelly, 2003:7). It was especially Vasari, the pioneer in the study of history of art as a scholarly discipline, who was strongly in favour of these daring artists. In the spirit of the sixteenth century humanism, Vasari in his Vite de' piu eccellenti pittori, scultori et architetti6 (1550), wrote with admiration of artists such as Fra Filippino Lippi's (1475-1504) abilities to imitate the antique grotesca. He praised Michelangelo's (1475-1564) fantastic inventions and virtuosity and described him as a genius who should not be constrained by any rules. It was precisely this virtuosity that revealed his divine talent (cf. Connelly, 2003:7). Connelly points out that Vasari expanded the concept of grotteschi from a technical term for a specific ornamental type to include the deliberate exaggerations and distortions of Michelangelo's sculpture and architectural designs.

As the seventeenth century advanced, the meaning chimera was transferred from anticke to grotesca and finally to grotesque (cf. Barasch, 1971:69). John Florio (1553-1625) the accomplished lin-

5 The word chimera refers to a monster of Greek invention consisting of the head and body of a lion and a serpent's tail. A second head, that of a goat, grows out of the lion's left side (Kleiner \& Mamya, 2005:241). 
guist, translator and lexicographer of the late sixteenth century, translated and explained the word grotesca as "antike, fretted or carved worke" in his Queen Anna's new world of words (1611). ${ }^{7}$ Summers (2003:23, 43 n. 13) explains that the word antic in (Old) English is derived from the Italian word antico, the whole phrase being antico grottesco. He refers to the Oxford English Dictionary, which stated that by 1624, grotteschi could be referred to as grotesca in Italian, or as antique work in English.

Two main schools of thought regarding the grotesque existed simultaneously at this stage. On the one hand there were the classical views, represented by the followers of Vitruvius, rejecting the grotesque. On the other hand were Vassari and his followers with a more "modern" view, praising it. Barasch (1971:31) points out that Horace's dictum was reinterpreted in the sixteenth century by Italian theorists in a typical humanist way as "a defence of artistic authority, asserting the artist's right to dare". In Northern Europe the grotesque style in ornamental art was also welcomed. This had more influence than Alberti's condemnation of the Dutch kermis painters. Chimera or "monster against nature" was the preferred meaning of grotesque during the first half of the seventeenth century (Barasch, 1971:69).

In the eighteenth century the classical notion of the grotesque once again became dominant and grotesque art fell into disrepute throughout Europe (Connelly, 2003:6-7).

\section{Notions of the grotesque in the nineteenth century}

During the nineteenth century Romanticism the two above-mentioned schools of thought co-existed. Connelly (2003:1-2) states that since the early nineteenth century it was no longer possible to describe the grotesque as peripheral to the visual arts. The Romantic period - in an attempt to challenge the universals of classical beauty - saw the grotesque entering into the mainstream of modern art as a means to explore alternative ways of expression.

7 Originally published as World of words in 1598. According to Barasch (1971:36) Florio also translated Montaigne's Essays (1603) in which the word grotesque occurs. Barasch states that the word anticke in Montaigne's eighth essay is used for the term grotesque in Tudor English. Barasch (1971:42) further explains that in Donne's Elegies (c.1603) death was brought into connection with anticke in the pun: "Death is not ancient but antique." In the Italian world there is an unproved, though interesting theory that Florio was in fact William Shakespeare. 
Victor-Marie Hugo (1802-1885), accomplished novelist, poet and dramatist of the nineteenth century condemned the restrictions imposed by French Classicism. His preface to Cromwell (1827) served as a manifesto for the Romantic Movement. In this preface Hugo (1827:31) declares - from a Christian perspective - that "the ugly [in creation] exists beside the beautiful ... the grotesque [beside] the sublime" and concludes that "[a]ll things are connected" (cf. also Barasch, 1971:153).

According to Barasch (1971:152) and Thomson (1972:15) Samuel Taylor Coleridge (1772-1834) and John Ruskin (1819-1900) in their analytical writings are the most important exponents in favour of the grotesque during the nineteenth century. In his Stones of Venice (1851-1853) Ruskin distinguished between "noble/true" grotesque and "ignoble/false" grotesque. He associated noble or true grotesque with the realisation of man's tragic, imperfect nature. Ignoble or false grotesque, he associated with unruly playfulness. In contrast to Hugo who combined beauty and grotesque in nature, Ruskin insists on the combination of the ridiculous and the terrible in the grotesque, and he associates the latter element with horror, anger or awe at the human condition (Thomson, 1972:15).

Carroll (2003:294) states that neo-classical art historians use the term grotesque as a term of abuse, while romantics use it as a term of praise (cf. also Barasch, 1971:10).

\section{Notion of the grotesque in the twentieth century and contemporary debates}

According to Jennings (1963) and Kayser (1981) the widespread interest in the grotesque during Modernism (since the nineteenth century) should not come as a surprise. The grotesque and related topics such as the absurd, the alienated, the social satire and the tragicomic, became the appropriate manner of expression of a time characterised by change and uncertainty. Jennings (1963:150) states that the grotesque represents the means of coping with the anxieties of an epoch, and that this is applicable to the use of the grotesque in the nineteenth and twentieth centuries' art. Jennings (1963:162) further identifies the grotesque as a mode of existence, comprising all the disorientation and uprootedness of the time, while Kayser (1981:185) explains that,

... it is our world which ceases to be reliable, and we feel that we would be unable to live in this changed world. The grotesque instils fear of life rather than fear of death. 
This alienated condition of man is linked to existentialism. Cornell (1993:419) suggests that postwar art often emphasised antihumanist feelings of alienation and isolation, closely mirroring the existentialist philosophy of Jean-Paul Sartre (1905-1980).

In his turn, Bakhtin (1895-1975) emphasises the creativity of the artist as well as the unsteadiness of the twentieth century (Connelly, 2003:5). He connects the notion of carnival with that of the grotesque in Rabelais and his world (1993), ${ }^{8}$ and describes the grotesque as

... a body in the act of becoming ... never finished, never completed, it is continually built, created, and builds and creates another body (Bakhtin, 1993:17).

Other uses of the grotesque than the expression of the instability of the century are highlighted by Carroll. Carroll (2003:309) remarks that the marked taste for the grotesque since the late twentieth century up to the present has more to do with leisure than with reflecting the spirit of the age. This seems true with regard to the numerous video games, animations, and film special effects. Carroll states that if the grotesque is regarded as a departure from the ordinary and set boundaries, it goes without saying that it will be a natural target for development as the entertainment industry expands. ${ }^{9}$

Currently the grotesque is found in several disparate developments and disciplines, such as the visual arts, mass media, mass culture, virtual reality, photography and science fiction (Carroll, 2003:291311). Authors writing on the grotesque in the twentieth century attempt to either provide a chronological overview and history of the use of the grotesque in art and literature or to study this phenomenon as a genre, a style or a specific category in the arts (Thomson, 1972).

Apart from new creations, it also includes imitations and a revival of the grotesque of previous centuries (Rosen, 1990:126). The grotesque continually figures prominently in expressionist, symbolist,

8 Originally published in 1941.

9 The use of the grotesque in the entertainment industry, as well as the relationship between the notion of the grotesque and gothic in the late 20th and 21st centuries is not discussed in this article. For a theoretical exploration in this regard, see Carroll (2003). 
realist, surrealist and abstract artworks (Carroll, 2003:291 ff.; Connelly, 2003:1).

Interesting enough, Connelly (2003:6) points out that, although the grotesque is at the heart of contemporary debates, and has been integral to the arts since the nineteenth century, it is noticeably absent in the filed of modern art-historical and aesthetic scholarship. This is so despite of the fact that a striking number of the period's most influential thinkers, including Baudelaire, Nietzsche, Freud, Bakhtin, and Kristeva have drawn from and reinterpreted the grotesque tradition.

Having provided an historical overview of the development of the grotesque, I now proceed to a discussion of the techniques typically used in artworks characterised as grotesque.

\section{Techniques associated with the grotesque}

\subsection{Introduction}

The following techniques have been identified as being commonly present in grotesque paintings and drawings: the presence of fusion figures or composite creatures, the violation and exaggeration of standing categories or concepts, and the juxtaposition of the ridiculous and the horrible (cf. Thomson, 1972). It goes without saying that not all these techniques are necessarily simultaneously present in each work. On the other hand an artwork may exhibit more than one of these techniques.

In what follows I will point out how these techniques feature in selected works in Western art and in Marley's creatures.

Since it is impossible to analyse all Western artworks dealing with the grotesque in this article, I have selected a number of works that in my opinion best illustrate the techniques used by the artists. Within the framework of the three techniques I will discuss the artworks in chronological order, starting with the oldest. This will sometimes result in discussing works originating in different eras in close proximity to each other.

In the case of Marley's drawings, I will provide a brief reading of each of the creatures-drawings. All Marley's creatures consist of fusion figures. I have, however, classified them under the different techniques according to where the artworks illustrate the specific technique best. 


\subsection{Fusion figures/composite, hybrid creatures}

Fusion figures or composite, hybrid creatures were part of the grotesque since its inception. Hybrid creatures of this type can be found "transculturally and transhistorically" (Carroll, 2003:294) ever since.

\subsubsection{Some examples of fusion figures in Western art}

While the grotesque in the form of composite and hybrid creatures in classical times was relegated to an ornamental role, these creatures in the Middle Ages mainly served as vehicles for portraying hellish and threatening forces in religious doctrine. It should be kept in mind that in medieval times art was almost exclusively under the patronage of the Roman Catholic Church. 10

The function of composite or hybrid creatures as bearers of religious doctrine is clear in for instance Gislebertus' marble sculpture Last judgment (c.1120-1135) which forms part of the Western tympanum of the St. Lazare cathedral in Autun, France. Gislebertus portrayed Christ in the centre, with the blessed souls to his left and the damned souls to the right. Composite and hybrid creatures in the form of demons and devils made up of human and insect features can be discerned. Kleiner and Mamiya (2005:464) describe them as follows: "Their gaunt, lined bodies, with legs ending in sharp claws, writhe and bend like long, loathsome insects." The grotesque in this work thus functions as a warning, a structure of estrangement to the people of the Middle Ages: they had to convert and believe in and act according to God's Word. This implies that they had to devote their services (and money) to the church alone. If not, these demons from hell will be their fate (cf. Carroll, 2003:295).

The same applies to Giotto's The last judgement (c.1304-1306), a fresco in the Capella degli Scrovegni in Padua, Italy. Here Satan is portrayed as a crossbreed with an obese human body and the head of a fearsome horned beast, devouring people and frightening them into obedience to the church.

Similar manifestations of the grotesque are found in fifteenth and sixteenth century Renaissance art, especially in Northern Europe.

10 The period circa 1000-1150, known as the Romanesque phase, witnessed the growth of church power throughout Europe. During the next period, the Gothic (c.1150-1400), the power of the church combined with the influence of prosperous towns to create unique European landmarks known as Gothic cathedrals (Fleming \& Marien, 2005:116). 
Examples are Martin Schongauer's (1448-1491) The temptation of St. Anthony tormented by demons (c.1490-1490); Hieronymus Bosch's (1450-1516) triptych Garden of earthly delights (c.1504), right hand panel Hell, and Matthias Grünewald's (1475-1528) right hand panel, The temptation of St. Anthony which forms part of the Issenheim altarpiece (c.1511-1516). In summary it can be stated that the grotesque in Gothic and Renaissance contexts typically have dark or ominous implications, urging viewers to act according to God's laws.

The following examples date from the twentieth century. The first is Pablo Picasso's (1881-1973) Les demoiselles de Avignon (1907). The grotesque in this painting serves as a vehicle to illustrate the condition of life in a brothel. The artist depicts the women with hard, sharp body curves and African masked faces, compressing the picture space to a two-dimensional area. The grotesque in this painting can also be interpreted as a grotesque objectification of women, who become vehicles for exploring geometrical shape and the manipulation of shallow painterly depth and space.

George Grosz (1893-1959) in his Republican automatons (1920) uses the fusion of human bodies and robot heads as unusual appearances. Here, unlike in Les demoiselles, the grotesque serves as a vehicle for social satire.

Salvador Dali (1904-1989) in his paranoiac-critical works, such as The great masturbator, (1929), Phantasmagoria (1930), The dream (1931) and Apparition of a face and a fruit dish on a beach (1938) gives way to surrealist composite creatures. The grotesque in these works portrays irrationalism. On the other hand, Belgian painter René Magritte (1898-1967) uses composite creatures in what seems to be a surrealist interpretation and revival of classical imitation views of the grotesque. In The flavour of tears (1948) a bird figure springs from plant leaves.

The grotesque in the composite creatures depicted in the paintings discussed, served different functions. While in the medieval example it served mainly as a vehicle for religious doctrine, it served a variety of functions in the examples of the twentieth century.

I now turn to a reading of three of Marley's drawings, namely Vampire, Canny and Froggies. I intend to provide a reading of the grotesque in these drawings. 


\subsubsection{Marley's fusion figures in his drawings: Vampire, Canny, Froggies}

\section{- Vampire}

Vampire is an especially fearsome composite creature. The drawing portrays a humanlike body with the wings of a bat attached to it. The creature has a bald head with three horns and four hissing snakes protruding from its head. An extra eye is placed in the middle of its forehead. It has short, sharpened teeth and two fangs. Its hands end in the claws of a bird of prey and fins grow out of each leg. The grotesque in this drawing can serve as a vehicle for aggression, ugliness, or even unknowable fears and enemies.

The creature depicted in Vampire has two normal eyes that seem to be blind. It also has an eye in the middle of is forehead, which is the only one that appears to be able to see. This eye in the middle calls to mind the Cyclops of Greek mythology: a one-eyed giant with an eye situated in the middle of its forehead.

Marley's depiction of the eye on the forehead of the creature also calls to mind the well-known painting Cyclops (1898) by the symbolist Odilon Redon (1840-1916). It portrays a presurrealist figure consisting mainly of a head and a single eye. The grotesque in Cyclops serves as a vehicle to symbolise the world of imagination.

\section{- Canny}

Canny is a birdlike creature with a tortoise shell for a back. It has two wings, a single feather for a tail and a canon that grows out of its head. It has two extra arms ending in robotlike clamps for hands and four legs and feet. While the feather appears harmless, it can change into a dragon tail. Marley indicates this by drawing with a very light charcoal pencil a dragon tail protruding from the feather tail. The grotesque in this somewhat humorous composite creature seems to tie in with the twentieth century's expansion of the entertainment industry, more specifically with video games.

Although it appears harmless, it is in fact armed with its own weapons in the form of a canon, clamps instead of hands and a changeable tail. As such the grotesque may portray the concept of the seemingly harmless. Living currently in South Africa where violent crimes have become part of daily life, the grotesque in this instance may serve as a metaphor for dangerous elements in society that appear at face value to be harmless. Alternatively it may serve as a warning to be constantly on alert. 


\section{- Froggies}

Froggies portrays a creature consisting of two frogs joined together at the lower parts of their backs, each with a snake tongue ending in thorny balls like tentacles. Each has three dragon horns on its back. When looking closely at the bodies of the combined frogs, one's eyes are tricked into seeing a giant butterfly. This "tricking of the eye" is a visual pun which is in a sense a conceptual fusion. The "butterfly" has froglike legs and claws growing out of its wings as well as two elongated whiskers growing - not in front of its head but from its wings - ending in two tentacles.

Seeing the creature as a fusion of two frogs, the grotesque can symbolise old age as frogs are the oldest living species. In this regard, wisdom is often connected with old age. Viewing Froggies as a butterfly, the grotesque may serve as a vehicle for freedom, as it can fly away. However, both frogs and butterflies are by their very nature metamorphoses and are characterised by constant change or fusion of one shape into another. In this regard Marley's Froggies represents a double fusion: conceptually and visually. This fusion calls to mind Kafka's Metamorphosis (1963 [1915]) of a man changed into a giant insect.

\subsection{Violations and exaggerations of standing categories or concepts}

Exaggeration of certain body parts is a technique used by artists to create the grotesque.

\subsubsection{Some examples of exaggerations in Western art}

This can be seen in two drawings of the Renaissance artist Leonardo da Vinci (1452-1519), namely Grotesque portrait study of man (c.1500-1505) and Caricature head study of an old man of the same period. Da Vinci affirms the sixteenth century artist's "right to dare" and uses the grotesque in an attempt to challenge the universals of classical beauty (Barasch, 1971). The grotesque in these drawings can also be read as comment on the decline of the human face due to ageing.

In his oil painting Christ carrying the cross (1490) Hieronymus Bosch painted grotesquely proportioned figures. In this painting he exaggerates the figures' noses, ears, mouths, chins and teeth, giving some of them squint-eyes. The grotesque portrays the people on their way to crucify Christ and thus serves to reveal the human 
stupidity, pitilessness and cunning cruelty of the crowd surrounding Him.

Thomson (1972:9) rightly observes that the grotesque has a strong affinity for physical abnormalities. The exaggeration of bodily parts can be seen in Dwarf (1642) of the Baroque artist Diego Velásquez (1599-1660). Another example occurs in the twentieth century in the work of the American regional artist, John Steuart Curry (18971946). His Baby Ruth (1932) depicts an obese little girl.

In the late eighteenth century, Henry Fuseli (1741-1825) and Francisco de Goya (1746-1828) were two of the first artists to use the grotesque in their attempt to depict the dark terrain of the human subconscious. Specialising in night moods of horror and dark fantasies such as the demonic and macabre, Fuseli in Nightmare 11 (1781) and Goya in his well-known The sleep of reason produces monsters (1798) use the grotesque as an escape from reality. The owl and the bat in the latter work is associated with the realm of witches and black magic. The use of the grotesque in the work of both these artists can be interpreted as a sign of their commitment to the creative process and to the Romantic spirit. It provided them with an opportunity to unleash their imagination, emotions, and even their nightmares (cf. Kleiner \& Mamiya, 2005:830).

Saturn devouring one of his children (1819-1823) is an oil painting which forms part of Goya's Black paintings. In showing Saturn devouring one of his children, Goya destabilises certainties and pushes the boundaries of normality. The concept of a father eating his own daughter is grotesque as it represents an absolute violation of the normal behaviour of a parent.

In expressionist artist Edvard Munch's (1863-1944) masterpiece The scream (1893) a central figure is portrayed whose face is distorted into a scull. Munch's use of the grotesque represents the anxieties of the time and the alienated condition of humanity. The distortion of the human figure is supported by the expressionist use of colour and brushstrokes in order to express modern humankind's inner world of fear, anxiety, anguish and despair.

11 Kleiner and Mamiya (2005:828) state that despite the temptation to see the painting's title as a pun because of the horse, the word nightmare is actually derived from the words night and Mara. Mara was a spirit in northern mythology that was thought to torment and suffocate those who sleep. 
Francis Bacon's (1909-1992) work Painting (1946) is also a manifestation of humanity's innermost alienation. His Scream - study for the head of a screaming pope (1952) depicts the grotesque in a way that corresponds with the techniques used by Munch. Although both artists emphasise humankind's alienated condition, the reasons for the alienation differ. In Munch's The scream the grotesque serves as a vehicle for loneliness and fatigue as the cause of despair. Bacon uses the grotesque to portray alienation stemming from nihilism and existentialism in his depiction of the pope with a wide gaping mouth.

In Soft construction of boiled beans (1936) surrealist Salvador Dali like Picasso in Guernica (1937) - explores the civil war in Spain. The grotesqueness of the horrors of civil war culminates in a gargantuan creature that dominates the picture space. It appears as though this creature has

dismembered itself, only to recombine in the most unspeakable mutation of the human body imaginable. It is an 'insane' monument to a fragmented Spain (Ross, 1990).

The grotesque form in this painting induces an uneasy and alienated emotional experience due to the unknown and violent form of the creature. Also, as in Bakhtin's Rabelais, the concept of the dismembering and recombining of the creature emphasises the instability of the twentieth century.

Another surrealist, Max Ernst (1891-1976), employs the grotesque in a different way in his The Virgin spanking Christ (1926). In this oil painting Christ is lying on Mary's lap. She is spanking Him while members of the surrealist movement look on through a window. Mary's face is skewed with rage and the child's buttocks have red marks on them. For the devout the grotesque in this painting may border on the blasphemous (cf. Steinberg, 2005:ix). The depiction of the red marks on the child's buttocks as well as the rage on Mary's face is grotesque because it implies maltreatment which is not the behaviour of a caring mother.

In the brief analysis of the above examples, the pushing of boundaries corresponds with Kayser's (1981) concept of the creation of a "world totally different from the familiar one". It is not always possible or easy to establish the exact intention of the artist, and one has to be very careful in attributing a specific intention to an artist. However, the intention of Max Ernst is quite clear when one reads the title of the work. 


\subsubsection{Violations and exaggerations in Marley's drawings: Fishy, Wolfie and Ostrigy}

I will now proceed to briefly analyse three drawings of Marley, Fishy, Wolfie and Ostrigy.

\section{- Fishy}

Marley departs from the familiar in giving the creature Fishy four eyes and three legs ending in claws. Fishy's mouth is transformed into a wide grimace showing its sharp teeth. The grotesque in this creature may call cruelty to mind, something that is emphasised by the grimace, sharp teeth and the snake it carries in its one claw.

In Greek mythology Argus, also called Panoptes (meaning the allseeing), was a giant with a hundred eyes. He had to guard one of Zeus' mistresses. Hermes, son of Zeus, killed Argus and Hera, Zeus' wife, stole the eyes and put them on a peacock. This story of cruelty invites a similar reading of Fishy.

\section{- Wolfie}

Wolfie depicts a wolf with a dragon tail and claws. Its body is covered, or camouflaged, with sheep wool. The sheep wool is not soft but looks like steel wool. The idiomatic expression "a wolf in sheep's clothing" is called to mind, indicating a person who is not to be trusted. This impression is confirmed by the ruggedness of Wolfie's wool. The dragon tail, claws and the bare teeth add to the impresssion of a dangerous creature, of something not to be trusted at all. Interpreted in this way, the grotesque serves as a vehicle for exposing hypocrisy.

\section{- Ostrigy}

A humorous addition to this category is Marley's drawing of an ostrich-cow-like creature called Ostrigy. The funny shape of the body with its finned feet and two small wings, ending at the one end in a long neck and at the other in a dinosaur tail, tends to elicit a smile. This creature could well serve as an illustration for a children's rhyme. Although Marley uses the techniques associated with the grotesque (namely a fusion figure, and an exaggeration of standing categories) in his depiction of a "cow cum ostrich" and in the process creates "a world different from the familiar one" it is an open question whether this work should be read as grotesque, since neither the concept nor the subject matter appears to be grotesque. 
It seems as though Marley - in his exaggeration of standards in Fishy and Wolfy - uses the grotesque mainly to serve as a vehicle for concepts such as cruelty and dishonesty. These two drawings also lack humour, which does not surprise, as cruelty and dishonesty is not funny concepts.

\subsection{Juxtaposition of the ridiculous and the horrible}

The last strategy to be discussed is the juxtaposition of the ridiculous and the horrible.

In an attempt to face one's private Angst and nightmares, artists often make use of a juxtaposition of the ridiculous and the horrible as a way of dealing with fear. Leo (1965:121) - in the context of the study of literature - suggests that there is in the psyche of both writer and audience a disarming mechanism in operation, which transforms the devilish mask into clownish make-up. In other words, the grotesque makes the fearsome less fearful, or devoid of fear, and even something to laugh at.

\subsubsection{Juxtaposition of the ridiculous and the horrible in Western art}

One of the best examples of this juxtaposition is Karel Appel's (1921-2006) Wild horse rider (c.1969), a figurative abstract expressionist work. An abstract human torso with wide staring eyes is painted against a bright red background. The wild horse - painted in blue - is placed a little behind the rider on the rider's left hand side (viewer's right hand side). To portray the concept of the rider's fear Appel uses grotesque devices such as exaggerated, wide staring eyes and vivid colours. The pupils of the eyes are painted in the same bright red as the background, suggesting fear. Paradoxically, the blue in which the wild horse is painted has a calming effect. The blue colour of the wild horse, as well as its position in the painting (rider's left hand side and a little behind the rider) suggests that the rider - despite his staring eyes - is in control. Fear, which is by nature a grotesque concept, is "tamed" in this painting. Appel succeeds in the "taming of fear" by using bright colours and painting in a childlike abstract form. The grotesque concept of fear experienced in riding a wild horse is now transformed into something to smile at.

The grotesque portraying in the juxtaposition of the ridiculous and the horrible in the following example does not serve as a way of dealing with fear. On the contrary, it highlights hypocrisy and the misuse of innocence. 
Austrian conceptualist Gottfried Helnwein (b.1948) is primarily concerned with psychological and sociological issues and anxieties. He participated in an exhibition at the Francisco Museum of Modern Art in 2000. The theme of the exhibition was The darker side of play land: childhood imagery from the Logan collection. Here he exhibited an oil painting, entitled Mouse I (1996), in which he depicts the well-known Mickey Mouse of Disneyland. Miller (2000) describes this work as follows:

Disney's favourite mouse occupies an entire wall of the gallery; rendered from an oblique angle, his jaunty, ingenuous visage looks somehow sneaky and suspicious. His broad smile, encasing a row of gleaming teeth, seems more a snarl or leer. This is Mickey as Mr. Hyde, his hidden other self now disturbingly revealed. Helnwein's Mickey is painted in shades of grey, as if pictured on an old black-and-white TV set ...

The theme of the exhibition already indicates the grotesque: it seems ridiculous and horrible to use the words "play land" and "childhood" in connection with "darker side" as the latter implies danger. In this case the mouse in a grotesque guise is a departure from the familiar. It destabilises the innocent beliefs associated with the well-known persona of this child friend.

The analysis of the above two paintings illustrates the different concepts with regard to the grotesque. Although the literature emphasises the positive use of the juxtaposition of the ridiculous and the horrible in the grotesque, it can also be used to serve the opposite function, that of inducing fear.

\subsubsection{Juxtaposition of the ridiculous and the horrible in Marley's drawings: Ducky and Rhino}

\section{- Ducky}

Marley's hybrid creature Ducky has a dragon tail, one big eye imitating a laser eye and claws for feet. Its body is covered with sheep fleece. Unlike Wolfie's, this creature's white fleece appears soft. The danger implied by laser eyes and claws is tempered by the softness of the fleece. Two wings, too small in relation to the rest of the creature's body, grow out of its back. The grotesque concept of danger, suggested by the laser eyes and claws, is tempered by the ridiculousness of adding soft sheep fleece and two small wings to a ducklike creature. This tends to elicit a smile. However, a dragon tail attached to a duck (which is normally seen as a harmless animal and is often depicted as a friend in children's literature), as well as 
the claws for feet and the big laser eyes can cause fear in a child. Fear is a horrible experience and a grotesque concept. But, through the juxtaposition of the ridiculous (softness of the fleece and the silly little wings) and the horrible (the claws, dragon tail and laser eyes) the grotesque concept of danger is nullified.

\section{- Rhino}

Rhino is a composite creature imitating a rhinoceros. It has two relatively small pairs of wings, one pair behind the ears and one pair at the rear end. Short sharp dragon horns grow out of its back and two rhinoceros horns grow on its nose. It also has a dragon tail. This drawing can be interpreted in the same way as Ducky. The juxtaposition of the ridiculous - two pairs of small wings attached to a rhinoceros - and the horrible - extra horns and a dragon tail - once again make the fearsome less so because of the implausibility of the depiction.

In both cases Marley uses this strategy to eliminate the grotesque concept of fear in a disarming way. To borrow Leo's words (1965), Marley's juxtaposition of the ridiculous and the horrible "transforms the devilish mask into clownish make-up".

\section{Summary}

This article provided an overview of the development of the grotesque and demonstrated that the grotesque in Western art history has served different functions in different epochs. The most salient or typical techniques used to suggest the presence of the grotesque were identified as the presence of fusion figures or composite creatures, the violation and exaggeration of standing categories or concepts, and the juxtaposition of the ridiculous and the horrible. These techniques were illustrated by a description of selected works in Western art and by a brief analysis of each of Marley' drawings in the Tracking creative creatures project.

\section{List of references}

BAKHTIN, M.M. 1993. Rabelais and his world. Trans. by H. Iswolsky. Bloomington: Indiana University Press.

BARASCH, F.K. 1971. The grotesque: a study in meanings. The Hague: Mouton.

BARASCH, F.K. 1985. The grotesque as a comic genre. Modern language studies, 15(1):3-11.

BROWNE, T. 2000 [1642]. Religio medici. http://penelope.uchicago.edu/ relmed/relmed.html Date of access: 20 Feb. 2008. 
CARROLL, N. 2003. The grotesque today: preliminary notes towards a taxonomy. (In Connelly, F.S., ed. 2003. Modern art and the grotesque. Cambridge: Cambridge University Press. p. 291-311.)

CONNELLY, F.S., ed. 2003. Modern art and the grotesque. Cambridge: Cambridge University Press.

CORNELL, S. 1993. Art: a history of changing style. Oxford: Phaidon.

FINGESTEN, P. 1984. Delimiting the concept of the grotesque. The journal of aesthetics and art criticism, 42(4):419-426.

FLEMING, W. \& MARIEN, M.W. 2005. Fleming's arts and ideas. 10th ed. Belmont: Wadsworth.

HARPHAM, G. 1976. The grotesque: first principles. The journal of aesthetics and art criticism, 34(4):461-468.

HORACE. 2000 [18 BC]. Ars poetica. The art of poetry: Horace in an epistle addressed to Lucius Calpurnius Piso and his two sons. Trans. by P. Francis. http://classicpersuasion.org/pw/horace/horacepo.htm Date of access: 15 May 2008.

HUGO, V. 2001 [1827]. Cromwell preface. (In Elliot, C.W. Prefaces and prologues to famous books. New York: Collier.) (The Harvard Classics series, vol. 39.)

JENNINGS, L.B. 1963. The ridiculous demon: aspects of the grotesque in German post-Romantic prose. Berkeley: University of California Press.

KAFKA, F. 1963 [1915]. The metamorphosis. Trans. by W. Muir and E. Muir. Harmondsworth: Penguin.

KAYSER, W. 1981 [1957]. The grotesque in art and literature. Trans. by Ulrich Weisstein. Bloomington: Indiana University Press.

KLEINER, F.S. \& MAMIYA, C.J. 2005. Gardner's art through the ages. 12th ed. Belmont: Wadsworth.

LAWSON, L.A. 1965. The grotesque in art and literature by Wolfgang Kayser. The modern language journal, 49(2):122-123.

LEO, E.J. 1965. The ridiculous demon: aspects of the grotesque in German post-Romantic prose by Lee Byron Jennings. Book review. The modern language journal, 49(2):121-122.

MILLER, A. 2000. The darker side of playland: childhood imagery from the Logan collection at SFMOMA. Artweek, US. 1st November. http://www. helnwein.com/presse/local_press/artikel_272.html Date of access: 25 May 2008.

ROSEN, E. 1990. Innovation and its reception: the grotesque in aesthetic thought. SubStance, $19(2 \& 3): 125-135$. (Special issue, 62/63.)

ROSS, A. 1990. The art of Salvador Dali: from the grotesque to the sublime. The grotesque in Western art, Spring. http://www.dr-yo.com/grot.html Date of access: 12 Feb. 2008.

STEINBERG, L. 2005. Max Ernst blasphemy. The New York review of books, 52(14):ix.

SUMMERS, D. 2003. The archaeology of the modern grotesque. (In Connelly, F.S., ed. 2003. Modern art and the grotesque. Cambridge: Cambridge University Press. p. 20-46.)

THOMSON, P. 1972. The grotesque. London: Methuen. 
Key concepts:

creative creatures

fusion figures

grotesque: unintentional

Marley, Ian

Western art history

Kernbegrippe:

groteske: onintensionele

kreatiewe kreature

Marley, Ian

saamgestelde figure

Westerse kunsgeskiedenis 
